\title{
Skin Response Group Identifier
}

National Cancer Institute

\section{Source}

National Cancer Institute. Skin Response Group Identifier. NCI Thesaurus. Code C117671.

A character or string that represents a skin response findings about group. 